\title{
ANNUAL REPORTS ON DEPARTMENT OF VETERANS AFFAIRS HEALTH- CARE UTILIZATION AMONG IRAQ AND AFGHANISTAN WAR VETERANS WITH TRAUMATIC BRAIN INJURY AND COMORBIDITIES TO INFORM POLICY, RESEARCH, AND PRACTICE
}

\author{
Brent C. Taylor, PhD, MPH; Nina A. Sayer, PhD
}

The past decade of research has demonstrated that a significant proportion of Veterans are returning from U.S. combat operations in and around Afghanistan and Iraq (referred to as Operation Iraqi Freedom, Operation Enduring Freedom, and Operation New Dawn [OIF/OEF/OND]) with mental health disorders, reintegration problems, and physical injuries [1]. While the Vietnam war heightened awareness of trauma-related mental health disorders, OIF/OEF/OND has heightened awareness of traumatic brain injury (TBI). In fact, because of TBI's relative prevalence compared with prior wars, it has become known as the "signature injury" of the wars in Afghanistan and Iraq. Factors that have contributed to the increased prevalence of TBI include not only higher rates of exposure to explosive munitions and postinjury survival but also improved detection as a result of Department of Defense and Department of Veterans Affairs (VA) TBI screening and evaluation programs.

To inform decisions that affect VA healthcare delivery for Veterans with TBI, VA needs information on these Veterans' healthcare needs, patterns of healthcare utilization, and costs. VA's Epidemiology Program within the Office of Public Health generates quarterly reports describing VA healthcare utilization among OIF/OEF/OND Veterans [2]. These reports present information on a wide range of medical and psychological conditions for which these Veterans seek VA healthcare [2]. However, they do not include TBI. Furthermore, the Epidemiology Program's reports do not describe patterns of comorbidity. Research has established that TBI in OIF/OEF/OND often co-occurs with mental health and pain-related disorders [1]. An understanding of the healthcare needs of Veterans with TBI, therefore, requires particular attention to comorbidity.

To address the need for information on the healthcare needs of OIF/OEF/OND Veterans with TBI, the VA's Polytrauma and BlastRelated Injuries (PT/BRI) Quality Enhancement Research Initiative
(QUERI) creates and distributes annual TBI utilization reports. These reports summarize the rate of $\mathrm{TBI}$, mental health, and pain comorbidities; VA service use; and healthcare costs in OIF/OEF/OND Veterans. The TBI utilization reports' appendices also detail methods for identifying TBI and characterizing healthcare use and costs in this population and, thus, are also a resource for researchers using VA administrative data.

PT/BRI QUERI utilization reports have covered fiscal years (FYs) 2009 through 2012 [3-6]. All these reports are available online (http://www.queri.research.va.gov/ ptbri/utilization_reports.cfm). It is now possible to compare across FYs, and in doing so, we see that there has been a substantial increase in the resources needed to care for Veterans of OIF/OEF/OND as a result of the 60 percent increase in the absolute number of these Veterans seeking care at VA facilities from FY 2009 to 2012. However, the rate of TBI in each year has remained relatively stable at approximately 7 percent. When we combine multiple years, however, we see that the prevalence of TBI increases. As shown in Table 3 of the FY 2012 utilization report [6], 9.8 percent of the 689,949 OIF/OEF/OND Veterans utilizing VA services over $3 \mathrm{FYs}$ received a TBI diagnosis. The rate of comorbidity has also been relatively stable. That is, the vast majority of Veterans with clinician-diagnosed TBI also had a clinician-diagnosed mental health disorder and approximately half of those with clinician-diagnosed TBI had both PTSD and a pain-related diagnosis. Perhaps not 
surprisingly in light of this comorbidity, these reports demonstrate that Veterans with TBI require substantially greater care than average Veterans of their same era without TBI. The median annual cost per TBI-diagnosed Veteran was more than three times higher than for those without TBI [6].

The TBI utilization reports provide populationbased information about OIF/OEF/OND Veterans that can be used for planning service delivery and informing research on VA patients with TBI and comorbid mental health and pain-related problems. At the time of this writing, 59 percent of OIF/OEF/OND Veterans had used VA for healthcare [2], a rate that far exceeds that of prior war eras. As the wars wind down, this information will continue to be of value to VA for planning and research purposes. The FY 2013 utilization report should be released in the fall of 2014.

\section{ACKNOWLEDGMENTS}

Funding/Support: This material was based on work supported by the VA, Office of Research and Development, Health Services Research and Development Service, Washington, DC, through a local-initiated project grant (PLY 05-2010-2) from the PT/BRI QUERI.

Disclaimer: The views expressed herein do not necessarily represent the views of the VA or U.S. Government.

Brent C. Taylor, PhD, MPH; ${ }^{1-3^{*}}$ Nina A. Sayer, PhD $^{1-2,4}$ ${ }^{1}$ Center for Chronic Disease Outcomes Research, Minneapolis VA Health Care System, Minneapolis, $\mathrm{MN} ;{ }^{2}$ Department of Medicine, ${ }^{3}$ Division of Epidemiology and Community Health, and ${ }^{4}$ Department of Psychiatry, University of Minnesota, Minneapolis, MN

*Email: Brent.Taylor2@va.gov

\section{REFERENCES}

1. Sayer NA, Carlson KF, Frazier PA. Reintegration challenges in US service members and veterans following combat deployment. Soc Issues Policy Rev. 2014;8(1): 33-73. http://dx.doi.org/10.1111/sipr.12001

2. Epidemiology Program, Post-Deployment Health Group, Office of Public Health, Veterans Health Administration, Department of Veterans Affairs. Analysis of VA health care utilization among Operation Enduring Freedom (OEF), Operation Iraqi Freedom (OIF), and Operation New Dawn (OND) Veterans: Cumulative from 1st Qtr FY 2002 through 2nd Qtr FY 2014 (October 1, 2001 March 31, 2014) [Internet]. Washington (DC): Department of Veterans Affairs; 2014 Jun. Available from: http://www.publichealth.va.gov/docs/epidemiology/ healthcare-utilization-report-fy2014-qtr2.pdf

3. Taylor BC, Hagel EM, Cutting A, Carlson KF, Cifu DX, Bidelspach DE, Sayer NA. Fiscal year 2009 VA utilization report for OEF/OIF veterans diagnosed with TBI. Prepared for the VA Polytrauma and Blast-Related Injuries QUERI \#PLY 05-2010-2 [Internet]. Washington (DC): Department of Veterans Affairs; 2011 Oct. Available from: http://www.queri.research.va.gov/ptbri/ docs/FY09-TBI-Diagnosis-HCU-Report.pdf

4. Taylor BC, Hagel EM, Cutting A, Carlson KF, Cifu DX, Bidelspach DE, Sayer NA. Fiscal year 2010 VA utilization report for Iraq and Afghanistan War veterans diagnosed with TBI. Prepared for the VA Polytrauma and Blast-Related Injuries QUERI \#PLY 05-2010-2 [Internet]. Washington (DC): Department of Veterans Affairs; 2012 May. Available from: http://www.queri.research. va.gov/ptbri/docs/FY10-TBI-Diagnosis-HCU-Report.pdf

5. Taylor BC, Hagel EM, Cutting A, Carlson KF, Cifu DX, Bidelspach DE, Sayer NA. Fiscal year 2011 VA utilization report for Iraq and Afghanistan War veterans diagnosed with TBI. Prepared for the VA Polytrauma and Blast-Related Injuries QUERI \#PLY 05-2010-2. [Internet]. Washington (DC): Department of Veterans Affairs; 2012 Sep. Available from: http://www.queri.research. va.gov/ptbri/docs/FY11-TBI-Diagnosis-HCU-Report.pdf

6. Taylor BC, Hagel Cambell E, Nugent S, Cutting A, Carlson KF, Bidelspach DE, Sayer NA. Fiscal year 2012 VA utilization report for Iraq and Afghanistan War veterans diagnosed with TBI. Prepared for the VA Polytrauma and Blast-Related Injuries QUERI \#PLY 05-2010-2 [Internet]. Washington (DC): Department of Veterans Affairs; 2014 Feb. Available from: http://www.queri.research. va.gov/ptbri/docs/FY12-TBI-Diagnosis-HCU-Report.pdf

This article and any supplementary material should be cited as follows:

Taylor BC, Sayer NA. Annual reports on Department of Veterans Affairs healthcare utilization among Iraq and Afghanistan War Veterans with traumatic brain injury and comorbidities to inform policy, research, and practice. J Rehabil Res Dev. 2014;51(7):vii-viii. http://dx.doi.org/10.1682/JRRD.2014.06.0155

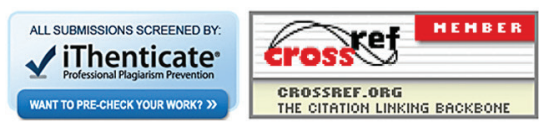

